\title{
THE TRUSTEE'S DUTY WITH REGARD TO. CONVERSION OF INVESTMENTS
}

\author{
George Gleason Bogert*
}

$I^{\prime}$

$\mathrm{N}$ THE course of the next few years there will doubtless be many efforts to surcharge trustees for failure to sell, or for delay in selling, or for selling, trust investments. Since 1929 the great reductions in the market prices of bonds and stocks, the defaults in interest payments, the passing of dividends, and the shrinkage of security margins on mortgages, have all raised questions as to the suitability of various trust investments. When to convert, or whether to convert at all, has been a perplexing problem, in view of the uncertainty of business conditions and the constant hope that there would soon be a turn for the better. ${ }^{\text {I }}$

It may be useful, therefore, to review and analyze the cases, statutes and opinions of writers bearing upon the questions of the duty of a trustee toward non-legal investments received from his settlor or from a predecessor trustee, and his duty with regard to investments made by himself which were originally legal but by change of circumstances have become non-legal. ${ }^{2}$

On such an important issue one might expect to find the law well settled and clearly stated. But there seems to be conflict and uncertainty.

\section{VIEWS OF TEXT WRITERS}

Lewin, ${ }^{3}$ the leading English text writer, gives no comprehensive treatment of the principles involved. He contents himself with summarizing the holdings in several cases and in calling attention to Section 4 of the English Trustee Act, 1925 , which has been in effect since $1894^{4}$

* Professor of Law, the University of Chicago Law School.

$x$ For collection of authorities and discussions of the general problem, see 37 A.L.R. 559 (I925); 57 A.L.R. II2I (I928); 77 A.L.R. 505 (I932); 36 Sol. J. \& Rep. 84I (I892); I Fiduc. Law Chron. 9; 30 Mich. L. Rev. 81 5 (1932); 9 Minn. L. Rev. 490 (I925); 79 Univ. Pa. L. Rev. 77 (I93I); I8 Va. L. Rev. 204 (I932); 4.Wis. L. Rev. III (I927); 65 U.S. L. Rev. 570 (I93I); 36 Law Notes 7 (I932); ro Tex. L. Rev. 393 (I932); 5 St. John's L. Rev. 59; 26 Sol. J. \& Rep. 396 (I882).

${ }^{2}$ For valuable papers on conversion and other investment problems in the depression, see Proceedings Thirteenth Midwinter Trust Conference, Feb., I932, pp. roI, I09, I18, 127, I36.

3 Lewin on Trusts ( $r_{3}$ th ed.), $26_{5}-6$.

${ }^{4} 57$ Vict., c. Io. 


\section{Another English writer ${ }^{5}$ states:}

Trustees have even in the absence of a power to postpone sale or a direction to retain securities, a discretion to be exercised in good faith, not to convert securities, even of a speculative nature, until the end of a year after the death of the testator...... If the conversion of any property is delayed beyond the year, the onus is upon the trustees to show why it was not brought into a proper state of investment.

The most frequently quoted American text-writer ${ }^{6}$ states:

There is said to be a distinction between an original investment improperly made by trustees and an investment made by the testator himself, and simply continued by a trustee; but it is a distinction that cannot be safely acted upon. When a trustee finds the estate committed to him already invested in securities which would not be legal investments for a trustee some courts hold that the trustee has no right to retain the unauthorized investments beyond a reasonable time for disposing of them. Other courts hold that the trustee will be justified in retaining such investments if he exercises reasonable prudence in doing so.

\section{Loring says:?}

Thus, where the maker of a trust transfers a partnership, business risk, speculative or unproductive property, to a trustee, or in fact any property which the trustee would not be authorized to invest in under the terms of the instrument or prevailing law, he must immediately and without delay proceed to convert all such property into investments authorized by the terms of the trust, and will have the implied power to do so.

The conversion should be made as soon as the trustee, in the exercise of a sound discretion, can make it. If he delays beyond a reasonable time, he will be liable for any loss of the property.

The late Judge Irvine in his excellent encyclopedic article on Trusts ${ }^{8}$ expresses the rule as follows:

Trustees may ordinarily, in the exercise of their discretion, retain such investments of the trust funds previously made by the creator of the trust as appear to be safe and proper investments, unless their subsequent depreciation, or threatened depreciation, renders it prudent to change them in order to protect the trust fund, in which case the trustees must act wisely in the emergency. Where there is no statute law or rule of court which points out any particular classes of securities for the investment of trust funds, the fact that securities were bought and held by the testator commends them for retention so long as there is no doubt of their safety. But where the investment is not such as is recognized by the rules of law applicable thereto, the trustee should sell and reinvest in accordance with such rules, and the fact that the testator himself made and approved of the investment will not relieve the trustee from responsibility for retaining it. Continuance of a speculation, like carrying stocks on margin, is never justifiable, in the absence of express permission.

5 Godefroi on Trusts ( $13^{\text {th }}$ ed.), 266.

${ }^{6}$ Perry on Trusts and Trustees (7th ed.), $\$ 465$.

7 Trustee's Handbook, I27-8. $\quad{ }_{39}$ Cyc. 409, 4Io (Igr2). 


\section{The problem is treated as follows in Ruling Case Law:}

When the trustee is not so authorized by the instrument creating the trust, it is the rule in some jurisdictions that he has no authority to continue beyond a reasonable time investments made by the creator of the trust in private corporate stock, but where the testator by his will directs the executors or trustees to continue his stock investments, they may properly do so. In other jurisdictions the rule is that where the trustee retains an investment in private corporate stock, acting in good faith and excercising a sound discretion, he is not responsible for depreciation in the value of the stock.

\section{THE RESTATEMENT}

Section 222 of the Restatement of the law of Trusts, prepared by the American Law Institute,,$^{\text {an }}$ provides:

Except as otherwise provided by the terms of the trust, the trustee is under a duty to the beneficiary within a reasonable time after the creation of the trust to dispose of any part of the trust property included in the trust at the time of its creation which would not be a proper investment for the trustee to make.

Section 223 of the Restatement provides:

Except as otherwise provided by the terms of the trust, if the trustee holds property which when acquired by him was a proper investment, but which thereafter becomes an investment which would not be a proper investment for the trustee to make, it becomes the duty of the trustee to the beneficiary to dispose of the property within a reasonable time.

\section{JUDICIAL EXPRESSIONS OF THE RULE}

If one looks to the language of the courts for the phrasing of a rule and ignores, for the moment, actual holdings, one finds a tendency to state the governing principle in either of two forms, which are at least theoretically different.

Some courts state the rule to be that the trustee who holds an investment not sanctioned by the settlor or by statute or by the decisions of the courts, has a duty to sell the security as soon as he can reasonably do so and reinvest the proceeds. ${ }^{{ }^{10}}$ He possesses no discretion to retain the investment if he thinks highly of it, when it is not one usually approved by the courts. He is to follow the statutory list, or other guides, without exception. The only questions left open to his decision are (I) Is the investment held by the trustee one which in its present condition would be ap-

${ }_{2} 6$ R.C.L. I3II (1926).

9a The reporter has been Professor A. W. Scott of the Harvard Law School.

ro This wording of the rule seems to be indicated in Clark v. Clark, $x 67$ Ga. $x$, I44 S.E. 787 (I928); Mobley v. Phinizy, 42 Ga. App. 33, I55 S.E. 73 (r930); Creed v. McAleer, 275 Mass. 353, 75 N.E. 76 I (x93 I); Hamersley's Estate, r8o N.Y.S. 887 (r920); Matter of Burr, 48 Misc. 56,96 N.Y.S. 225 (1905); Matter of Yung, ro3 Misc. 358 , 170 N.Y.S. 303 (x918) (guardian); Mills v. Hoffman, 26 Hun 594 (1882), reversed on another point in 92 N.Y. I8I (1883); Gillespie v. Brooks, 2 Redf. 349 ( 1876 ); Cannon v. Quincy, 65 Misc. 399, I2x N.Y.S. $75^{2}$ (rg09); In re Leitsch's Will, 185 Wis. 257,201 N.W. 284 (r924). 
proved by the court as a new investment, under the application of the statute or court rules? (2) When is it reasonable to sell the investment, if it is found to be a "non-legal"? He is not permitted to decide that in the special circumstances of the case in question the ordinary rules of original trust investment shall not be applied to the retention of this particular investment and that it shall be kept indefinitely.

If, for example, the trustee holds mining stock which would not be a proper purchase as a trust investment under the statute or court rules, but the trustee believes that the purchase of the stock by the settlor and the extraordinary evidence of the success of the mine justify him in refusing to sell the stock and in holding it indefinitely for the trust, under the terms of this rule he must make such a decision at his own risk. If his judgment proves good, the cestui will reap the benefit; but if the mining adventure is in the long run unsuccessful, the trustee may be held liable for breach of his absolute duty to convert the non-legal investment within a reasonable time.

This rule of absolute duty to convert non-legals has been explained by a Georgia court in the following words: II $^{-}$

The power of a trustee to retain investments received from the creator of the trust is, in the absence of contrary statute or provision in the instrument creating the trust, not different from his power to make investments. . . . We deem the safe and better rule to be that trustees who receive investments made by the creator of a trust, not in securities authorized by our law, should, in the absence of directions to retain them, dispose of such securities, and invest the proceeds in such other securities as are authorized by our law. If they do not take this course, then, to relieve themselves of a liability for a loss, they should submit the matter of the continuance of such investments to the judge of the superior court, and procure an order for the retention of such securities, if the judge deems it wise and prudent and to the best interests of the beneficiaries that the investments should remain as made by the creator of the trust.

For this rule it may be urged that it is a natural implication from the positive statutory rules about investing trust funds. The statutes are usually expressed in language referring to the purchase of new investments, as are some of the rules of reasonable prudence in those states having no statutory lists. They generally make no express reference to retaining investments, except in some special cases, later discussed. ${ }^{\mathbf{2}}$ But these statutes and rules of court may well be interpreted to mean that the trustee shall neither buy as a new investment nor retain as an old investment any except securities of the named classes. There is just as much risk of loss to cestuis from keeping a speculative or unsecured old investment as from making a new investment of that type.

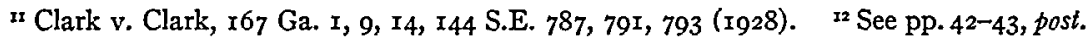


It may also be urged with some force that trust instrument clauses permitting a trustee to retain old investments in his discretion are now so common in trust instruments that the absence of such a paragraph has some tendency to lead to the conclusion that the settlor expected the trustee would soon conform all the trust investments to the statutory or court types.

The second form in which the rule about a duty to convert is sometimes stated by the courts is slightly different. Some courts have said in effect that a trustee holding a non-legal, whether delivered to him by another or purchased by himself, has a duty to convert the security within a reasonable time and reinvest in legals, except in extraordinary cases where he decides to retain the investment for the trust, after having acted in good faith and with reasonable diligence and prudence. ${ }^{x 3}$ This rule would seem to recognize that in the great majority of cases due care would require the conversion of an investment which the trustee could not properly then buy as a new investment, but it seeks to give the court a slight leeway in which to protect the trustee where very special circumstances have reasonably led him to decide not to sell a particular non-legal investment. The trustee is given the privilege of varying the statutory or court rules about investments in exceptional cases.

In discussing this rule a Pennsylvania court has recently said ${ }^{14}$ that

they [the authorities] indicate the view that each case where a trustee retains unauthorized securities, purchased by his decedent, must be judged to a certain degree by its own peculiar facts, and the hard and fast rule, restricting original investments by trustees, does not apply with imperative force. The general rule,--in jurisdictions which, like Pennsylvania, limit the investment of trust funds,-is that ordinarily a fiduciary has no right to retain, beyond a reasonable period, investments made by the decedent in unauthorized securities, unless specially empowered to do so; that when a trustee continues to possess such non-legal investments after a time when he could properly dispose of them, and a loss occurs, he may be held liable for a failure of due care, unless he shows that his retention of the securities in question represents, not a mere lack of attention, but the honest exercise of judgment based on actual considera-

${ }_{23}$ This phrasing seems to be recognized in Johns v. Herbert, 2 App. D.C. 485 (I894); Bowker v. Pierce, 130 Mass. 262 (I88I); State Street Trust Co. v. DeKalb, 259 Mass. 578, I 57 N.E. 334 (I9I 7); Beam v. Paterson Safe Deposit \& Trust Co., 8r N.J.Eq. I95, 86 Atl. 369 (I9I3), 83 N.J.Eq. 628, 92 Atl. 35I (19I4); Jones v. Jones, 2 N.Y.S. 844 (I888); In re Parson's Estate, 143 Misc. 368, 257 N.Y.S. 339 (x932); In re Jarvis' Estate, rro Misc. 5, r80 N.Y.S. 324 (I920); Taylor's Estate, 277 Pa. 5I8, I2x Atl. 310 (r923); Brown's Estate, 287 Pa. 499, I35 Atl. II 2 (I926); Linnard's Estate, 299 Pa. 32, I48 Atl. 9 I 2 (I930); Coggins' Appeal, 3 Walker 426 (Pa.); Rhode Island Hospital Trust Co. v. Tucker, r6o Atl. 465 (R.I. I932); In re Allis' Estate, I9I Wis. 23,209 N.W. 945 (I926).

${ }_{4}$ Taylor's Estate, 277 Pa. 518, 528, I2I Atl. 310, 313 (r923). 
tion of existing conditions; in other words, he is expected to be ordinarily watchful and to exercise normal good judgment.

And a New York court has also expressed itself in similar language::5

We are not inclined to lay down a hard and fast rule in respect of this matter. When a trustee finds the estate committed to him already invested in interest-bearing securities, we are not inclined to say that it is his absolute duty at once to dispose of them, without regard to the market, or the demand for them, or the ruling price, or the probability of an advance in their value. It is sufficient to say, however, that, ordinarily, if a trustee sees fit to continue such investments after he shall have had a reasonable opportunity to sell them without loss and to invest them in those securities which by law he is authorized to hold, it must be an exceptional case which will justify him in his failure to do so where as a result of that failure there has been a loss.

While this second rule seems at first consideration to give the courts a greater measure of freedom than the other doctrine, it is believed that both rules have a modicum of elasticity. Under the first rule the trustee has a reasonable time within which to convert, and if there has been a retention which the court wishes to sanction, it can do so by holding that the trustee used reasonable judgment in deciding that the proper time for conversion had not yet arrived. Under the second rule the court can free the trustee from responsibility for the retained investment, either on the theory that ordinary care was used in deciding that it was not yet time to convert, or on the assumption that the case was a special one, in which it was good judgment to determine to hold the security indefinitely.

In states where there is no statutory list of trust investments, and the whole matter is left to the rule of the use of reasonable prudence, the courts have still further freedom of movement in the conversion cases. If they desire to protect the trustee, they can hold that he used ordinary prudence in deciding that the investment in question was a legal investment, and hence that the problem whether he should be under a duty to convert, and when, never arose at all.

It would seem that the same rules with respect to conversion should be applied both to the case of an investment which is without the permitted class at the time it is received into the trust, and also to investments originally lawful for trustees but which become non-legal because of a change in property values or a shift in the financial position of the obligor in the security. In neither case is there any express or implied permission to retain coming from the settlor, the court or a statute. In both instances there is a danger to the cestui which should place some duty upon the trustee with respect to a change in investments.

ss Matter of Wotton, 59 App. Div. 584, 587, 69 N.Y.S. 753, 754 (rgor); aff'd. without opinion, I67 N.Y. 629,60 N.E. II 23 (IgOI). 


\section{THE DECISIONS}

The decisions show numerous instances of trustees held liable for failure to convert trust investments at all or in due time, ${ }^{16}$ as well as many cases where the courts excused the trustee on the ground that he acted reasonably in delaying the sale of the investment in question or in not selling at all. . $^{\text {? }}$

It is often difficult, if not impossible, to tell whether a decision represents an application of the rule of absolute duty to convert or of a rule requiring the trustee to use reasonable prudence with respect to conversion..$^{8}$ If $T$ has received from the settlor corporate stock which is not on the legal list and he retains it five years until it becomes worthless, he would doubtless be held liable whether the rule were in the first or second form. He has failed to obey an absolute duty to convert in a reasonable time, and he has also failed to use reasonable care about converting. If $T$ held the stock for three years and then sold it for less than he could have received at the end of one year, the decision surcharging $T$ might be explained either on the ground that he had delayed too long in performing his absolute duty to convert, or on the basis of a failure to act with regard to the conversion in a reasonably prudent manner.

In some of the decisions where advice was given to a trustee with regard to conversion, or he was surcharged or freed from liability, it seems fairly clear that the theory of action was the existence of an absolute duty to

${ }^{16}$ Sculthorpe v. Tipper, L.R. I3 Eq. 232 (1879) (should have converted shares of unlimited banking company within one year); Snyder's Admrs. v. McComb's Ex'x., 39 Fed. 292 (r889); Johns v. Herbert, 2 App. D.C. 485 (r894) (trustee with lack of power to sell depreciating securities should have applied to court for power to sell); Mobley v. Phinizy, 42 Ga. App. 33, r55 S.E. 73 (I930) (liable for assessment on bank stock held); Clark v. Clark, I67 Ga. I, I44 S.E. 787 (1928); State Street Trust Co. v. DeKalb, 259 Mass. 578, I 57 N.E. 334 (1927); Creed v. McAleer, 275 Mass. 353 , 175 N.E. $76 \mathrm{r}$ (r93I); In re Belcher's Estate, I29 Misc. 2I8, $22 \mathrm{I}$ N.Y.S. $7 \mathrm{Ir}$ ( 1927 ) (failure of administratrix to sell rights to subscribe); In re Hamersley's Estate, I80 N.Y.S. 887 (x920); Mills v. Hoffman, $26 \mathrm{Hun} 594$ (I882), reversed on another point in 92 N.Y. I8r ( 1883 ) (trustee holding bank stock three years liable for assessment on stock); Taylor's Estate, $277 \mathrm{~Pa}$. 5I8, I21 Atl. 310 (I923).

${ }^{17}$ Bowker v. Pierce, I30 Mass: 262 (I88I); Ogden v. Allen, 225 Mass. 595, II4 N.E. 862 ( $\operatorname{Igr}_{7}$ ) (reasonable delay); Beam v. Paterson Safe Deposit \& Trust Co., 83 N.J.Eq. 628, 92 Atl. 35I (I914); Furniss v. Cruickshank, I9x App. Div. 450, I8I N.Y.S. 522 (x920) (real property held for ten years; just after panic of 1873 ; property bringing in good rental and finally selling for fair price); In re Parson's Estate, I43 Misc. 368, 257 N.Y.S. 339 (I932) (will probated in January, I929; held till after collapse of security market in October, 1929); In re Allis' Estate, I9I Wis. 23, 209 N.W. 945 (1926).

${ }^{18}$ See, for example, Ogden v. Allen, 225 Mass. 595, II4 N.E. 862 (1917); In re Hamersley's Estate, I80 N.Y.S. 887 (r920). 
convert within a reasonable time; ;9 while in other cases the rationale of the holdings seems to be the existence of a duty to act with the care of an ordinarily prudent man with regard to conversion or retention..$^{20}$

\section{CONTROL, BY SETTLOR}

It is, of course, elementary that a settlor may permit or direct a trustee to retain investments originally placed in trust, or may permit or direct the trustee to convert such investments coming from the settlor. ${ }^{2 \mathrm{I}}$

A trustee will normally be protected in following the settlor's permission to retain or convert ${ }^{22}$ and will normally be liable for any damage suffered by reason of failing to follow a direction to retain or to convert. ${ }^{23}$ However, the trustee must use some care in following either the settlor's directions or permissions. This view is supported by several decisions,

${ }^{39}$ Clark v. Clark, 167 Ga. I, I44 S.E. 787 (1928); Mobley v. Phinizy, 42 Ga. App. 33, I 55 S.E. 73 (1930); Creed v. McAleer, 275 Mass. 353, I 75 N.E. 76r (193 ); Babbitt v. Fidelity Trust Co., 72 N.J.Eq. 745, 66 Atl. 1076 (I907); Matter of Burr, 48 Misc. 56, 74, 96 N.Y.S. 225 (Igo5); Matter of Yung, I03 Misc. 358, I70 N.Y.S. 303 (I918); Gillespie v. Brooks, 2 Redf. 349 (N.Y. I876); In re Leitsch's Will, I85 Wis. 257 , 201 N.W. 284 (rg24).

${ }_{20}$ Medland v. Medland, $4 \mathrm{r}$ Ch. Div. 476 ( $x 889$ ) (no duty to call mortgage the instant margin falls below two-thirds; duty to act reasonably); In re Chapman, (1896) 2 Ch. 763 (no absolute duty to convert mortgage at once on depreciation of security); Bowker v. Pierce, 130 Mass. 262 (I881); State Street Trust Co. v. DeKalb, 259 Mass. 578, 57 N.E. 334 (1927); Beam v. Paterson Safe Deposit \& Trust Co., 83 N.J.Eq. 628, 92 Atl. 35I (Igr4); In re Jarvis' Estate, IIo Misc. 5, r80 N.Y.S. 324 (1920); Jones v. Jones, 2 N.Y.S. 844 (I888); Dauler's Estate, 247 Pa. 356, 93 Atl. 5 II (I9I5); Taylor's Estate, 277 Pa. 518, I21 Atl. 3 ro (I923); Rhode Island Hospital Trust Co. v. Tucker, I6o Atl. 465 (R.I., I932); In re Allis' Estate, I9I Wis. 23, 209 N.W. 945 (1926).

2x Dircction to retain: Rhode Island Hospital Trust Co. v. Bradley, 4I R.I. 174, ro3 Atl. 486 (IgI8) (where directed to retain securities, though "hazardous and doubtful," trustee may keep securities notwithstanding they are unproductive). Permission to retain: Fraser v. Murdock, 6 A.C. 855 (I88I); York v. Maryland Trust Co., I49 Md. 608, I3I Atl. 829 (r926); North Adams National Bank v. Curtiss, 278 Mass. 47 , 180 N.E. 217 (1932). A direction to retain investments held by the settlor cannot by parol be added to a trust created by will. Citizens' \& Southern National Bank v. Clark, I 72 Ga. 625, I 58 S.E. 297 (I931).

${ }_{22}$ Effect of permissive language: York v. Maryland. Trust Co., x49 Md. 608, x3I Atl. 829 (I926); North Adams National Bank v. Curtiss, 278 Mass. 471, I80 N.E. 217 (I932); In re United States Trust Co., 189 App. Div. 75, I 78 N.Y.S. I25 (Igro). In In re Linnard's Estate, 299 Pa. 32, r48 Atl. 9r2 (I930), the court refused to charge the trustee for retaining investments as authorized by the testator. It was alleged that the trustee trust company owed the cestuis a duty to refuse the authorization and to sell, because it was prudent to do so; but the court held that settlor's authorization was complete protection.

${ }^{23}$ Effect of mandatory language: Strong's Estate, I60 Pa. x3, 28 Atl. 480 (x894). That the trustee acted in good faith and carefully in violating the settlor's instruction is not important. Crayton v. Fowley, I $40^{\circ}$ S.C. $5^{1} 7$, I39 S.E. I6I (1927). If the failure to follow the directions results in no loss, the trustee is obviously not liable. McKinney's Estate, $260 \mathrm{~Pa}$. 123, $103 \mathrm{Atl}$. 590 (rgI8). 
some of which do not relate to retention or conversion but rather relate to the making of investments.

Thus, if the settlor has given the trustee discretion as to making investments, it is to be implied that the settlor means that the trustee may select such investments as he thinks best after the honest exercise of reasonable care. It is not a natural interpretation of such a clause to hold that it gives the trustee the privilege of choosing any investment, no matter how speculative or ill-secured. Under such a clause the trustee will be protected if he has in good faith used the care of an ordinarily prudent man in selecting the investment; ${ }^{24}$ but he will not be relieved of liability for losses caused by reckless conduct.25

If a trustee is authorized by the settlor to retain securities held by the settlor, this permission is not absolute. It implies, however, that the trustee will be protected in retention unless it becomes very apparent that it will be disastrous to keep the investments. ${ }^{26} \mathrm{~A}$ Pennsylvania court has stated the principle to be that trustees who follow a direction or permission to retain will not be held liable for loss occasioned by such action unless "facts known to them, or which by ordinary watchfulness could have been known to them, rendered the holding of such securities an act of which it is inconceivable that one desiring to do his duty would, in the exercise of ordinary good business judgment or foresight have been guilty." ${ }_{27}$

While the disobedience of directions to retain or convert is undoubtedly at the risk of the trustee, and the cautious trustee will almost always follow such directions, cases can be imagined in which a court would probably hold a trustee liable for failure to disobey the directions. For example, if a trustee is directed to retain the settlor's investments in a stock and the stock ceases to pay dividends and begins to decline in price, it may be that such a clear case of duty to disobey the instructions can be presented that the trustee would be liable for the damages caused by failing to sell.

The courts are not inclined to extend the settlor's directions or permissions with regard to the retention or conversion of trust investments beyond the clear and apparent meaning of such clauses. The settlor's

$24 \mathrm{McCoy}$ v. Horwitz, $62 \mathrm{Md}$. 183 ( 1884 ); In re Allis' Estate, I23 Wis. 223 , Ior N.W. 365 (1904); and see Hart's Estate, 203 Pa. 480, 53 Atl. 365 (Ig02).

${ }^{25}$ See notes I62 L.T. 27 (I927); 26 Col. L. Rev. 453 (I926).

${ }^{26}$ In re Clark's Estate, I36 Misc. 88I, 242 N.Y.S. 210 ( $x 930$ ), noted in 30 Col. L. Rev. I I66 (1930), affirmed 257 N.Y. 132, I77 N.E. 397 (I931); Matter of Frank, I24 Misc. 664, 208 N.Y.S. 254 (I925); In re Detre's Estate, 273 Pa. 34r, II7 Atl. 54 (r922).

${ }_{77}$ In re Linnard's Estate, 299 Pa. 32, 37, 148 Atl. 9r2, 9I4 (I930). 
language, which it is alleged enlarges the trustee's investment powers, is strictly construed. ${ }^{28}$

\section{CONSTRUCTION OF THE SETTLOR'S LANGUAGE}

When the settlor permits or directs the trustee to keep described corporate shares, some difficult questions arise concerning the identity of substituted corporate securities upon a merger, consolidation or reorganization of the original corporation. If, considering the character of the business to be carried on by the new or revised corporation and the rights and liabilities of the shareholders, the new shares represent substantially the same type of investment, they may be retained under the settlor's authorization; but if in any material respect there has been a change in the nature of the activity, or in risk, security, or priority, the new property ought not to be held under the authorization clause.

Very careful consideration is necessary to determine whether there is substantial identity. An authorization to permit the trust fund to remain in its present state of investment does not allow the trustee to hold shares which are not fully paid up, which were substituted for those paid up.9 In In re Smith, ${ }^{30}$ an English court held that permission to keep specific stock made it lawful to hold stock issued by a new corporation organized to take over the business of the old, where the trustees had no part in bringing about the reorganization and were obliged to take the new shares or cash. The court thought there was merely a technical difference between the two corporations and their shares. This decision was questioned in In re Anson's Settlement, ${ }^{3 \mathrm{x}}$ where the court held that permission to hold stock of the Northern Securities Company, a holding company, did not permit the trustees to retain the stock of the Great Northern and Northern Pacific Railroad companies, where the holding company was dissolved by court order, this even though the holding company had been holding stocks of these two operating companies. The court thought there was a material difference between an interest in the holding company and stock rights in operating companies.

Permission to retain the "same securities" as held by the settlor makes it legal to hold the settlor's stocks. ${ }^{32}$ The word "securities" is not construed to mean promises to pay secured by liens on property.

${ }^{28}$ In re Sir S. M. Maryon-IVilson's Estate, (Igr2) I Ch. 55 (phrase "British colony or dependency" does not include a province of Canada); Clark v. Clark, $167 \mathrm{Ga}$. I, 144 S.E. 787 1928); In re Franklin Trust Co., 84 Misc. 686, 147 N.Y.S. 885 (rgr4).

29 In re Morris, 54 L.J.Ch. 388 ( 1885 ).

${ }^{30}$ (IgO2) 2 Ch. 667.

${ }^{3 x}$ (I907) 2 Ch. $424 . \quad{ }^{32}$ In re Rayner, (Ig04) x Ch. I76. 
In a leading New York case ${ }^{33}$ there was a direction to retain stock of the $S$ corporation, which later merged with the $X$ corporation to form the $Y$ corporation. The trustee received shares in the $Y$ corporation in return for those of the $S$ corporation, but did not feel authorized to retain the former and sold them. The court held that this sale was proper and not a violation of the settlor's direction, since the new shares were not substantially identical with the old. The new shares were common shares and subordinated to some preferred stock. The court said:34

We think the identity of the Shuttleworth shares was ended by the merger, and that the trustee had the power to sell what was acquired as a substitute. . . . Here the investment is radically different. The change of identity has relation not to form only, but to substance. The tale is only partly told when we say that the consolidated corporation is a new juristic person. It is that, but it is something more. The new shares have been issued in new proportions and classified in new ways, as common and preferred. The old investment has been subordinated to alien priorities. The ancient venture has exposed itself to strange and unexpected hazards. The finding is that there has been a change in the 'product manufactured,' the 'marketability of the product,' the 'capital structure,' and 'risks and vicissitudes,' both actual and probable. We think the trustee was not subject to a duty to keep within the trust an interest differing in substance from the interest in the business as it stood at the time of the foundation.

In the same jurisdiction authority to hold stock of the old Standard Oil Company has been construed as not justifying retention of the shares of thirty-three different subsidiaries received after the dissolution of the parent company. ${ }^{35}$

In two Massachusetts decisions ${ }^{36}$ the stock of a consolidated or reorganized company has been deemed to be substantially identical in character with that of the old stock which was marked for holding by the settlor. But national bank stock has been treated as differing in important ways from the stock of a state bank formed by the merger of the national bank with a state institution. ${ }^{37}$

If a corporation issues stock in order to capitalize undivided profits, power to retain the original stock should apply to the new shares. ${ }^{38}$

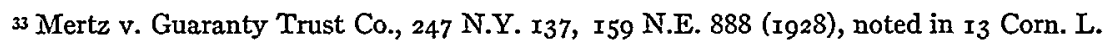
Quar. 638 (1928). And see In re Herriman's Estate, 142 Misc. I64, 254 N.Y.S. I58 (r93I), where the court held there were not sufficient facts before it to decide the question of identity.

${ }^{4}$ Speaking through Cardozo, C.J., at p. I4I.

35 In re Franklin Trust Co., 84 Misc. 686, I47 N.Y.S. 885 (Igr4).

${ }^{6}$ Old Colony Trust Co. v. Shaw, 26 r Mass. I 58 , 158 N.E. 530 (r927) (stock in mining companies left; these consolidated with others); Anderson v. Bean, 272 Mass. 432, 172 N.E. 647 (r93o) (original company sold assets to new corporation).

${ }_{37}$ Bass v. Adams, 163 S.C. $38 \mathrm{r}$, I6r S.E. 697 (r93

${ }^{38}$ In re Whitfield, (1920) W.N.Cas. 256. 
Neither the trustee's interest in the corporation nor his investment of trust capital is increased by accepting the shares which represent the distribution of profits.

Quite often where a settlor has directed or authorized a trustee to hold stock, the corporation issuing the stock grants to stockholders the right to subscribe to new shares at a figure lower than the market price. While it is doubtless the duty of the trustee to take advantage of this opportunity by selling the subscription right, ${ }^{39}$ or by exercising it if he can legally purchase securities of the type offered, it seems dubious whether an authority to hold the old shares ought to be construed as warranting the trustee in investing trust capital in the new shares, if they are not such investments as would be permissible to him, without regard to the settlor's directions. The new shares, obtained by use of the subscription rights, are not in exchange for the old shares. They involve an increase of the trust investment in the particular corporate adventure. That the settlor authorized leaving the value of the old shares in this corporate risk does not seem to lead to the conclusion that he was willing that an additional sum should be invested thus. ${ }^{40}$

A power to continue stock investments of the settlor has been held to cover stocks of a wasting character, ${ }^{4 \mathrm{I}}$ since the settlor knew of that factor. A power to continue investments naturally means to hold for an indefinite period and not merely until the trustee can find an opportunity to sell them advantageously.42

${ }^{39}$ In re Belcher's Estate, 129 Misc. 2I8, 221 N.Y.S. 7 II (I927).

40 In re Pugh, (I887) W.N. Cas. I43; In re Davison's Ex'rs., I34 Misc. 769,236 N.Y.S. 437 (rg29), aff'd. 230 App. Div. 867 (r93o). But if the settlor leaves stock to trustees, with a direction to retain it and to preserve the investment, he may be held to have authorized buying new shares when the capital is doubled, in order to maintain the size of the interest of the trust estate in the corporation. In re Tower's Estate, $253 \mathrm{~Pa} .396,98 \mathrm{Atl}$. 576 (I9r6). And a New Jersey court has permitted a trustee to use a cash dividend to buy stock under subscription rights, saying, "It seems to me that having the right to take the stock, which after it was taken, gave them no greater interest in the company than they had before-merely changed the form of their holding-they have the right to retain it. The authority given by the will is 'to continue any investments or securities.' By agreeing to take the company's stock in exchange for the company's money they are merely preserving their proportionate interest in the property, and so doing nothing more than continuing their investment in it." Ballantine v. Young, 79 N.J.Eq. 70, 73, 8I Atl. II9 (I9II). The problem would seem to be whether the settlor meant that the trustee should maintain the share of control in the corporation in question or should merely keep the funds already invested in the enterprises allocated to that stock. The normal instruction or permission to retain stock would seem more naturally construed to permit the keeping of the original certificates or their successors, but not the placing of any more capital in the same corporation.

4 In re Inman, ( I9 $\left._{5}\right) \times$ Ch. 187.

${ }^{42}$ Old Colony Trust Co. v. Shaw, 26I Mass. 158 , 158 N.E. 530 (I927). 
If trustees are given discretion to postpone a sale of non-legal investments or to hold them indefinitely, they must unite in exercising that discretion. If they cannot agree, their duty is to sell, as required by the statute or the instrument. ${ }^{43}$ The making of the exception is a discretionary function, in which all trustees must unite unless the instrument has given a majority power to act.

Where there is an express direction to convert securities, the English court has treated one year as a reasonable time within which to carry out the mandate of the settlor. ${ }^{44}$

A power to retain stock, the holders of which were under an obligation to buy bonds of the corporation when it needed money, has been held to imply a power to advance trust funds for the purpose of purchasing such bonds, thus increasing the investment in the corporation. ${ }^{45}$

If a settlor directs that specific securities be held by the trustee as the original subject matter of the trust, there is an implied direction not to convert, of course, but the trustee may come under an obligation to sell the securities later, if a serious change in their condition occurs. ${ }^{46}$

\section{COURT CONTROL}

A court of equity may control the matter of retention or conversion of trust securities..$^{47}$ A trustee who is in serious and justifiable doubt as to the existence of a duty to convert or retain, may apply to the court for advice. $4^{8}$

The courts are loath to interfere with the investment management of the trust if such interference involves overriding directions of the settlor or of the governing statute, ${ }^{49}$ but in cases of emergency they will, no doubt,

${ }_{43}$ Re Roth, 74 L.T. 50 (1896); In re Hilton, (r909) 2 Ch. 548; Re Lever, 76 L.T. 7 I (1897).

${ }_{44}$ Sculthorpe v. Tipper, L.R. I3 Eq. 232 (1879).

45 Farmers' Loan \& Trust Co. v. Hewitt, 94 N.J.Eq. 65, II8 Atl. 267 (I922), aff'd. 94 N.J. Eq. I87, II8 Atl. 926 (1922).

$4^{6}$ Ward v. Kitchen, 30 N.J.Eq. 31,36 (1878).

${ }^{47}$ See Price v. Long, 87 N.J.Eq. 578 , Ior Atl. I95 (I9I 7), where the court directed a sale of stock in a jewelry corporation which the settlor had instructed the trustee to retain; and Richardson v. Knight, $69 \mathrm{Me} .285$ ( $\times 879$ ), where, under a statute giving the court power to determine the "mode of executing a trust and the expediency of making changes and investments of property held in trust," the court directed the sale of depreciated shares of stock, although the settlor had not given any power of sale or reinvestment. The power of a court to order a conversion is often expressly given to the court by statute, and the court may use that power, even against the wishes of cestuis. Gleason v. Hastings, 278 Mass. 409, I80 N.E. I 29 (I932).

${ }^{48}$ Rhode Island Hospital Trust Co. v. Tucker, I60 Atl. 465 (R.I., I932); In re Leitsch's Will, I85 Wis. $257,20 I$ N.W. 284 (r924).

49 See Re Crawshay, 60 L.T. 357 (I888), where the court held it would not override the settlor's directions to retain shares in a partnership and accede to the trustee's wish to incorporate 
act with regard to retention or conversion in order to guarantee carrying out the fundamental purpose of the trust and for the purpose of preventing serious injustice.

A Kentucky statute ${ }^{50}$ gives trustees power to convert trust investments when in their opinion a sale would be for the benefit of the estate, but stipulates that no executor or administrator shall sell "any dividendpaying stocks, bonds or other security which the decedent owned at his death," unless ordered to do so by the court.

The Iowa statute ${ }^{5 x}$ provides that a trustee may, by consent of the court or by virtue of permission in the trust instrument, retain investments received by him or the increase thereof.

\section{EFFECT OF BENEFICIARY'S CONDUCT}

The beneficiary's conduct may prevent him from objecting to the retention or conversion of an investment. The operation of the principle that the cestui may estop himself is found throughout the trust investment cases.

Thus, if a competent beneficiary, with full knowledge of the facts, and not led thereto by any improper conduct of the trustee, requests a trustee to make a non-legal investment, or consents thereto formally or informally, such cestui will not be heard lạter to complain of damage flowing from the investment. ${ }^{22}$

If the improper investment has already been made, the cestui may approve or ratify it in such a way as to make it inequitable that he thereafter sue the trustee for damages..$^{53} \mathrm{He}$ may accomplish this result, either by a direct statement to that effect which leads the trustee to retain the investment and not to perform his duty to convert; 54 or he may indirectly

the business and take shares in lieu of the partnership interest. For other cases where the court refused to interfere with the trustee's ordinary investment duties, see In re Morrison, (rgor) . I Ch. 701; In re Tollemache, (1903) I Ch. 457, 955; Gaines v. Arkansas National Bank, 280 S.W. 993 (Ark. I926); Hackett's Ex'rs. v. Hackett's Devisees, I80 Ky. 406, 202 S.W. 864 (I918); York v. Maryland Trust Co., I49 Md. 608, I3I Atl. 829 (Ig26); Clark v. Clark, 32 Misc. 272, 50 N.Y.S. 104I (1898); Burrill v. Sheil, 2 Barb. 457 (N.Y. I848). (Igo7).

so Ky. Carroll's St. 1930, $\$ 4707$. And see Chappell v. Chappell, r24 Ky. 69r, 99 S.W. 959

${ }^{2}$ Iowa I93I Code, § $1277^{2}$.

$5^{2}$ Ford v. Wilson, to Del. Ch. I24 (Igr4); Lannin v. Buckley, 256 Misc. $78,{ }_{52}$ N.E. 7 I (1926); Mann v. Day, I99 Mich. 88, I65 N.W. 643 (1917); In re Hall, I64 N.Y. I96, 58 N.E. II (I90); Fisher v. Fisher, I 70 N.C. 378 , 87 S.E. II3 (I9I 5); In re Detre's Estate, 273 Pa. 34I, II 7 Atl. 54 (I922); Davis v. Davis Trust Co., I07 W.Va. I4r, 147 S.E. 490 (Ig29).

53 Brown's Estate, 287 Pa. 499, 135 Atl. II2 (I926).

st Willis. v. Holcomb, 83 Ohio St. 254, 94 N.E. 486 (I9I I); In re Armitage's Estate, I95 Pa. 582,46 Atl. II7 (1900). 
achieve the same end by accepting the benefits of the improper investment with knowledge of its character. ${ }^{55}$ An express release of the trustee for a breach of trust with regard to an investment has the same effect, ${ }^{56}$ but is based on a slightly different theory. It recognizes a cause of action for breach and discharges it, while the approval, ratification, or estoppel conduct binds the cestui to the position that he cannot assert that any cause of action ever existed.

As with all other direct dealings between trustee and cestui, so with transactions alleged to have amounted to a validation of an otherwise improper investment there must be full and fair disclosure by the trustee of all the knowledge he possesses. ${ }^{57}$ There must be no concealment or misrepresentation by the trustee..$^{8}$ The cestui must be of full age and sound mind.

One cestui cannot affect another beneficiary's rights in this regard. ${ }^{59}$ For example, consent to a non-legal investment by a life tenant cestui has no bearing upon the ability of the remainderman cestui to complain. ${ }^{60}$

\section{STATUTES REGARDING RETENTION OR CONVERSION}

In a number of jurisdictions there are statutes affecting the problem. In one group of statutes permission to retain investments received from the settlor is given. In the Illinois ${ }^{6 r}$ and South Carolina $a^{62}$ statutes this permission is unqualified and extends to all trustees. In the California, ${ }^{63}$ Minnesota, ${ }^{64}$ and Washington ${ }^{65}$ statutes it is unqualified, but extends only

${ }_{5 s}$ Mulford v. Mulford, 53 Atl. 79 (N.J.Eq., I902); In re Detre's Estate, 273 Pa. 34r, II7 Atl. 54 (I922).

${ }^{6}$ In re Allis' Estate, I9I Wis. 23,209 N.W. 945 (r926).

57 White v. Sherman, 168 Ill. 589, 48 N.E. I28 (1897); Mann v. Day, I99 Mich. 88, 165 N.W. 643 (r9I7); Appeal of Pray, 34 Pa. 100 (1859).

${ }_{58}$ "Having been induced by the fraudulent representations to consent to the investment, the case should be treated as though no consent was given." Murphy-Bolanz Land \& Loan Co. v. McKibben, 236 S.W. 78, 8ז (Tex. I922).

59 Neither the majority of the cestuis in number or in interest can affect the right of the remaining cestuis to charge the trustee for breach of an investment duty. In re Deare, i I T.L.R. 183 (I895).

${ }^{60}$ Brown v. Williams, 29 Ohio Cir. Ct. Rep. 25 (rgo6); International Trust Co. v. Preston, ${ }_{24}$ Wyo. I63, I56 Pac. Ir 28 (rgI6). But patently if the life cestuis consent and the remaindermen beneficiaries are not injured, there is no cause of action against the trustee for a bad investment. Lannin v. Buckley, 256 Mass. 78 , 152 N.E. 7 (I926).

6r III. Cahill's Rev. St. r93r, c. 3, § I44; Smith-Hurd's Rev. St. I93r, c. I48, § 32. This section was added to the Illinois laws by L. I905, p. $x$.

62 S.C.L. I929, Act $1_{32}$.

${ }_{63}$ Cal. Gen. L. r931, Act 652, § 105.

64 Minn. Gen. St. I923, § 7735 .

65 Wash. Pierce's Code rg29, \$ 298. 
to trust company trustees. In the Connecticut ${ }^{66}$ and Oregon ${ }^{67}$ statutes the permission to retain the settlor's investments is unqualified and is coupled with a statement that the trustee shall not be liable for a depreciation if he follows the statutory permit. The Connecticut statute applies to all trustees, but the Oregon statute only to trust companies.

Recent New York legislation ${ }^{68}$ has in effect given trustees authority to retain certain bonds temporarily although they do not now meet the statutory requirements for legal trust investments.

Section 4 of the English Trustee Act, 1925, , provides that "a trustee shall not be liable for breach of trust by reason only of his continuing to hold an investment which has ceased to be an investment authorized by the trust instrument or by the general law." The retention of a non-legal is not of itself a breach of trust, but the trustee has a duty to use due care in deciding whether the investment which was originally legal but has now become non-legal should be sold.

The new Ohio Probate Code ${ }^{70}$ in substance requires the trustee to convert non-legals only if an ordinarily prudent business man would consider them unsuited for the trust and "ripe for sale." It places no absolute duty on the trustee to sell non-legal investments.

Delaware $^{7 x}$ and New Jersey ${ }^{72}$ statutes protect a trustee who in good faith in the exercise of reasonable care retains an investment received by him from the settlor or another and not purchased by the trustee himself.

Just as equity has required a trustee to use some degree of care in following the permission or direction of the settlor to retain or convert trust investments, so it is believed that the trustee in following statutory directions or permissions will be required to act in a reasonably careful manner. Even though the statute permits the trustee to retain the settlor's investments, it is hardly conceivable that the court will excuse the trustee from the duty to use good judgment in retaining such investments if there is a clear showing that serious damage will accrue to the trust from such retention. It is believed that the trustee will be liable if he does not convert.

${ }^{66}$ Conn. Gen. Code I930, $\$ 4836$. And see Beardsley v. Bridgeport Protestant Orphan Asylum, 76 Conn. 560,57 Atl. 165 ( $\left.x_{904}\right)$.

${ }_{7}$ Ore. Code 1930, $\$ 22-I_{214}$.

${ }^{68}$ N.Y.L. I932, c. 5 .

${ }^{4}$ I 5 I 6 Geo. V, c. I9.

TO Ohio 193I Probate Code, § 10506-42. 7Del. L. I93I, c. 259.

${ }_{72}$ N.J. Comp. St. Igro, p. 227r, par. 34. For construction see Coddington v. Stone, $3^{6}$ N.J. Eq. 36r (I883); Brown v. Brown, 72 N.J.Eq. 667, 65 Atl. 739 (1907). In In re Eckert, 93 N.J. Eq. 598, II 7 Atl. 40 ( 1922 ), the court charged an executor who had delayed four years in selling bonds received from his testator. 
THREE CLASSES OF INVESTMENT RULES

In a number of jurisdictions there is no statutory list of trust investments, and the trustee is merely required to invest with reasonable skill and prudence. ${ }^{73}$ In these jurisdictions it would seem that the trustee's duty with regard to conversion or retention could be stated in similar language. He is required to perform all acts with regard to investments with the wisdom and caution of a reasonably prudent man-not only the acts of original investment but the acts of reviewing investments, of deciding to retain investments, of deciding to change investments, and of conducting sales of investments. In these states it seems unnecessary and perhaps improper to state the duty with regard to conversion in terms of the duty with regard to original investment. Where a trustee finds a doubtful security in his hands in these jurisdictions, he should not ask himself the question whether it would be proper to buy such security at the present time, but whether reasonable skill and prudence requires a retention or a conversion.

In another large group of states the legislature has fixed a list of investments for trustees. In some jurisdictions the statutes are worded in such a way as to make the statutory list apparently exclusive. In these states the legislature has said in substance that the trustee shall invest in named securities and none others. ${ }^{74}$ While such statutes by their exact terms seem to apply only to the purchase of securities, they ought reasonably to be construed to cover retention. They may with justice be held to mean that a trustee shall neither purchase himself, nor retain after having received from another or having purchased himself, any security which does not come within the terms of the statutory list. There is just as much danger to the beneficiary in keeping a non-legal security as in the purchase of it.

In states where this mandatory list is fixed by statute, the strongest possible case is presented for an absolute duty to convert an investment not on that list. Still it is believed that the statute must be applied with a certain amount of discretion and judgment and cannot be followed blindly. If a trustee has actual knowledge that the obligor in an investment on

73 This seems to be true in Arizona, Indiana, Maine, Maryland, Massachusetts, Michigan, Mississippi, Missouri, Montana, Nevada, New Mexico, and Rhode Island.

74 Cal. Gen. L. I93r, Act 652, § 105 (trust companies only); Rules of D.C. Sup. Ct., No. $7 \mathrm{I}$ (court will ordinarily sanction only listed investments); Fla. L. I93r, c. I5064; Idaho L. I929, c. $20 ;$ N.H. Pub. Laws I926, c. 309; N.D. Comp. L. I9I3, § 5216; Ore. Code I930, § 22-I216; Vt. Gen. St. I9r $7, \S 5363$ (applies to banks and trust companies only); Wash. Pierce's Code r929, $\S 298$. The Iowa statute ( $\$$ I2772, Code r93r) provides that all trust investments must be submitted to the court in advance, and that investments shall be made from the approved list. 
the list has defaulted in the payment of interest or principal, surely the trustee would not be protected in purchasing such a security. And so, too, if the trustee is holding an investment on the list but has actual knowledge that the obligor is in serious financial difficulties, surely no court would excuse the trustee for failing to act to save the investment before a catastrophe had occurred.

Some of the other statutes prescribing lists of trust investments are permissive in form. They provide that a trustee "may invest in the following securities," naming them. ${ }^{75}$ Where such a permissive list is fixed by the legislature, it seems clear that the trustee must use reasonable judgment in following the list either in making the original investments or in retaining old investments. This principle of duty to use ordinary care in following statutory lists is expressly stated in the statutes in Delaware, ${ }^{76}$ Illinois, ${ }^{77}$ and Minnesota ${ }^{78}$ and should be implied in other permissive statutes. The same principle applies with regard to authorizations to retain or convert given by the settlor himself.

\section{ELEMENTS WHICH SHOULD INFLUENCE THE TRUSTEE}

The considerations which should move the trustee in deciding whether to convert or to retain are numerous and depend upon the character of the investment, the condition of the market, and the status of the trust. Some of the factors which may reasonably be considered are the following: a serious depreciation in the market price of the investment, ${ }^{79}$ a noticeable

75 Ala. Code 1923, $\$$ ro413; Ark. Act 215, L. 1931; Colo. L. I93r, c. 55; Conn. Gen. Code 1930, \& 4836; Del. L. 1931, c. 259; Ga. Code 1926, \& 3763; Ill. Cahill's Rev. St. 1931, c. 3, par. r44; Kan. Rev. St. 1913, §§ 40-307; Ky. Carroll's St. I930, § 4706; Minn. Gen. St. r923, § 7735; Neb. Comp. St. 1929, $\$ \$ 8-206$ (trust companies only); N.J. Comp. St. x910, p. 227I, par. 35; N.Y. Dec. Est. Law, \$ III, Pers. Prop. Law, \$2x; N.C. Code I93r, \$ 40I8; Oh. Prob. Code I93I, \$\$ I0506-4r; Okla. St. I93 I, \$ 921 I (trust companies); Pa. Purdon's r93o St., Title 20; $\$ 801$; S.C. Laws 1929, Act 132; S.D. Comp. L. 1929, \$ 9049 (trust companies); Tenn. Pub. Acts 1931, c. 100; Tex. Vernon's Ann. Civ. St., Art. 5 II (banks and trust companies); Va. Code I930, $\$ 543 \mathrm{I}$; W.Va. Off. Code $193 \mathrm{I}, \mathrm{C} .44$, art. $6, \S 2$ (no liability for an investment in a security on the statutory list); Wis. St. I93I, $\S 231.32$; Wyo. L. I925, c. $157, \S 73$ (trust companies). Section $\mathrm{I}$ of the English Trustee Act is permissive in form, also.

${ }^{76}$ Del. L. I93I, c. 259.

$\pi$ Ill. Cahill's Rev. St., c. 3 , $\$$ I44. ${ }^{8}$ Minn. Gen. St. $1923, \S 7735$.

79 In re Jarvis' Estate, I 10 Misc. 5, 180 N.Y.S. 324 (I920). In Beam v. Paterson Safe Deposit \& Trust Co., 83 N.J.Eq. 628,92 Atl. 35 I (19I4), the trustees were not held liable for failure to sell railroad bonds which first depreciated but slightly and then became worthless. Evidently the first change was not enough to cause a duty to sell and the second was so sudden and catastrophic that it was good judgment to hold for a return of value. The court said (pp. 62930):

To hold that so slight a variation in the market required the trustee to sell would, in effect require a trustee to watch the 'ticker' as a mere speculator might. This is not the duty of a trustee. He is to invest in safe productive securities and mere fluctuations in market price which 
diminution in the value of the property which secures the investment, ${ }^{80}$ an important adverse change in the financial situation of the obligor in the investment, ${ }^{8 x}$ any default by the obligor in the payment of interest or principal of the investment obligation or his other obligations, the fact that the investment is in the nature of a wasting asset,,$_{2}^{82}$ that property which secures the investment is unproductive or diminishing in productivity, ${ }^{83}$ that the security is quoted above par and is approaching matur-

may be due to variations in the current rate of interest or in the current demand for ready money in panic or war, ought not to force him to sell. Were it otherwise it would be practically impossible to invest a trust fund with any approach to permanence, and the loss of interest on the constant reinvestment might be a serious loss to cestui que trust. These considerations suffice to show that the date fixed by the vice-chancellor cannot be justified. We cannot, however, leave the case at that, since, subsequently, the securities became practically worthless, and a rapid fall began in the summer of $x 9 \circ 7$. This is shown to have been a time of financial depression when the best securities dropped in value. We think that even then the trustee was not required to sell, since great shrinkages take place at such time which are subsequently recovered; the trustee might be held liable for loss if he sold when the market was low and there was a subsequent recovery.

${ }^{80}$ State Street Trust Co. v. De Kalb, 259 Mass. 578 , I57 N.E. 334 (I927) (trustee held mortgage on property which for ten years was depreciating in value to his knowledge; held liable for not foreclosing). And see In re Salmon, 42 Ch. Div. 35I (r889), where it was held that a successor trustee had a duty to convert a mortgage for $£_{1300}$ on laborers' cottages valued at $£_{r} 75^{\circ}$, and that the successor did not owe his predecessor a duty to give him an opportunity to take over the mortgage before a sale of it, although there would have been such a duty in the case of an investment not within the terms of the trust. In Medland v. Medland, 4I Ch. Div. 476 (I889), the court considered the duty of a trustee holding a mortgage where the margin decreases below the required level, and said (p. 48r):

I do not think it was their duty when the value of any of the securities first fell below one and one half times the amount of the mortgage debt to proceed at once to call in the mortgage debt, and to reduce it to a sum representing only two thirds of the then value of property. One of the reasons why a margin of one third is required in the case of a mortgage of a free hold estate is to provide for fluctuations in the value of the property. I do not think, therefore, that the fact that such a diminution had taken place in the value of the property as made the mortgage debt a little more than two thirds of the value was a reason why the mortgages should at once be called in.

And see In re Chapman, (1896) 2 Ch. 673 , requiring a trustee holding a mortgage with decreasing security merely to use reasonable care and good faith about converting. If the cestui thinks the margin inadequate, he may apply to a court for an inquiry into the subject. In re D'Epinoix' Settlement, (rgr4) I Ch. 890.

${ }^{8 x}$ In Bowker v. Pierce, $x_{3} \circ$ Mass. 262 (r88I), stock left to a trustee by the settlor gradually fell in value and the company issuing the stock met with reverses. In holding the trustee not liable for a failure to convert, the court said (pp. 263, 264):

In deciding whether he would sell this stock, all that was required of the trustee was that he should act with good faith and in the exercise of a sound discretion. . . . . We can now see that it would have been wise to sell the stock. But in judging his acts we should put ourselves in his position at the time. He was considering the question, not whether he should invest in this stock, but whether he should sell the stock bought by the testator, upon a falling market. The evidence shows that he in good faith made investigations, sought information from trustworthy sources, and acted upon such information to his best judgment. We are of opinion that the presiding justice who heard the case rightly found that, under the circumstances, the trustee acted in good faith and with the sound discretion which the law requires of him.

8ะ See M'Millan, Wasting Subjects in Residuary Trust Settlements, 36 Scot. L. Rev. 197.

${ }_{3}$ In Babbitt v. Fidelity Trust Co., 72 N.J.Eq. 745, 66 Atl. 1076 (1907), a trustee held un- 
ity ${ }_{2}^{8_{4}}$ or that the investment in question involves risking an excessive amount in a single venture or type of activity..$^{85}$

The elements which may properly lead a trustee to decide when to convert where he has a clear duty to sell, or which may justifiably influence him to determine to retain the non-legal indefinitely where the court permits him that choice in special cases, include the sacrifice in trust capital which a sale at any given time will involve, the probability that the investment in question will increase or decrease in market value in the future, the possibility that the security being considered may return to the legal list at a later date, and the effect of the sale, if any, upon the remainder of the trust property. ${ }^{86}$ It is believed that the courts will permit trustees faced with conversion problems during the depression beginning in I 929 to consider the effect on the general security market of dumping large masses of trust securities. That such large general conversions of trust assets would reduce the market value of other trust properties and bring on a duty to sell still other securities at a large loss, is a fact which may well influence a trustee to postpone conversion. A conversion involving a sale at a figure much below the original or inventoried value of the investment will doubtless not be encouraged.

\section{SUMMIARY}

I. Where there is not a controlling court rule or order, statute, or settlor's instruction or permission,

a) some courts require a trustee who holds non-legals to convert them

authorized stock which brought in only about one and a half per cent. The court said (p. 757):

There was therefore no reason, properly viewed by the trustee, to induce it to hold an unauthorized security, paying so little, at a time when the market for its sale was open and a large price could have been obtained for it, and that price could have been invested in authorized securities to yield a rate of interest at least three times greater than that received from the then investment.

In Rhode Island Hospital Trust Co. v. Tucker, I60 Atl. 465 (R.I. I932), the court advised a trustee to convert stocks which were paying little or no cash income, stock dividends being considered not income.

${ }_{84}^{8}$ Taylor's Estate, 277 Pa. 5I 8, I2I Atl. 3 ro (I923) (bonds were received at r25, but held until maturity nine years later and paid off at par).

${ }^{85}$ For a case where the distribution question was important, see In re Dreier's Estate, 204 Wis. $22 \mathrm{r}, 235$ N.W. 439 (x93r).

${ }^{86}$ In North Adams National Bank v. Curtiss, 278 Mass. 47 r, I80 N.E. $2 \times 7,222$ (1932), the court said:

The fact that these investments were made by the testator and not by the trustee, that he was known as a man of sound business judgment, as well as the fact that he had made provision in his will for the guidance and protection of any trustee thereunder, were matters to be considered by the trustee in deciding what course of action should be followed in regard to holding or disposing of the securities. The trustee also was warranted in giving some consideration to the fact that a sale of the securities at a large profit would result in a large tax. 
within a reasonable time after he acquires them or after they become nonlegal; but

b) other courts merely require the trustee to exercise the care of an ordinarily prudent man with regard to retention or conversion of nonlegals.

2. In practice these two rules probably bring about identical results.

3. The second of the two rules seems preferable in form.

4. If a trustee is given permission by the settlor, the court, or a statute to retain or convert, he has a duty to use the care of an ordinarily prudent man in making his decisions.

5. If a trustee is directed by the settlor, the court, or a statute, to retain or convert, he has a duty to use at least slight care in following the direction, and may not give blind or thoughtless obedience to the direction.

6. The courts probably will be very lenient with trustees who in good faith have made decisions with regard to retention or conversion during the period of extreme uncertainty and depression since $1929 .{ }^{87}$

${ }_{87}$ The tendency to take notice of times of war or depression is observable in the cases. Beam v. Paterson Safe Deposit \& Trust Co., 83 N.J.Eq. 628, 92 Atl. 35I (I9I4); Furniss v. Cruikshank, I9r App. Div. 450, I8r N.Y.S. 522 (I920); In re Stort's Estate, r 42 Misc. 54, 253 N.Y.S. 834 (r93I). 